Rev. Marian Zając

John Paul II Catholic University of Lublin

DOI: 10.15290/rtk.2019.18.11

iD 0000-0002-2940-5154

\title{
Extracurricular Activities: A New Catechetical Challenge
}

Since the 1990s, when religious education began to be offered once again in Polish public schools, a disturbing phenomenon has been observed: more and more students are choosing not to participate in religious education classes. This problem is more prominent in Poland's largest cities. The purpose of the present article is to point out new ways to use modern extracurricular activities to engage and attract young students who have abandoned religious education. Such extracurricular activities must be voluntary, different from typical school activities, and appeal to students' current interests. Research demonstrates that the most frequent reason why students opt not to participate in religious education classes is not because they oppose what the courses teach, but because they are too lazy to participate in them. Creatively organized extracurricular activities can be a great catechetical opportunity to counteract Polish students' tendency to cease participating in religious education at school.

Key words: religious education, extracurricular activities, evangelization, Gospel, Church .

Religious education is offered in Polish public schools as a part of the curriculum and organized in accordance with the law to students whose parents or legal guardians request in writing that their children participate. However, after becoming an adult (i.e., reaching the age of 18), students themselves are permitted to decide whether or not they will participate in religious education. It is not compulsory for a student to participate in religious education at school. However, once a student or his parents declare in writing an intention to participate in these classes, participation becomes compulsory. Legally, however, 
it is possible to change one's decision and withdraw from religious education. In such circumstances, an adult student or his parents or legal guardians must submit in writing the intention to withdraw. Once done, the principal then notes the decision on the letter stating the student's original intention to participate. ${ }^{1}$

If a student does not take part in religion or ethics classes at school, then he does not receive a grade for these classes. ${ }^{2}$ This, however, is not the greatest concern of those responsible for organizing religious education. A much more serious problem is the fact that many students are refusing to participate in religious education classes altogether-a trend that is already very evident in major cities throughout Poland. ${ }^{3}$ In addition, students are also more reluctant to learn about their faith by memorizing prayers, studying dogmas, and following obligatory moral principles. An increasingly individualistic worldview and postmodern thinking, which forbid religion to have a voice within the public square, have played a role in these negative trends. What can we suggest to slow down or reverse such disturbing outcomes? Extracurricular religious activities might be part of the solution. ${ }^{4}$

\section{Organizing Extracurricular Time Creatively}

In his apostolic exhortation Christus Vivit, Pope Francis refers to the Gospel and appeals to young people to make every effort to preserve the faith. ${ }^{5}$ He believes that it is necessary to make the most of every time and circumstance to re-establish formative contact with catechumens who have abandoned religion classes. Passages from the Gospel indicate that it is possible to re-establish contact with such

1 Ustawa z 7 września 1991 r. o systemie oświaty (tekst jednolity: Dz.U. z 2004 r. nr 256, poz. 2572 ze zm.) - art. 44 b ust. 7 .

2 Por. Guidelines to assess the academic achievements in religion(Roman Catholic) taught at school. August 25, 2008. Issued by the Polish Episcopal Conference's Commission onCatholic Education, KWEP-C-464/08.

3 Por. A. Głowacki, Religijność młodzieży i uczestnictwo wlekcjach religii w szkole, in: Centrum Badania Opinii Społecznej, Młodzież 2018, Warsaw 2018, pg. 163.

Por. L. Zaleśny, Zajęcia z religii - czy sa przedmiotem dodatkowym? https:// www.portaloswiatowy.pl/organizacja-zajec-szkolnych/zajecia-z-religii-czy-saprzedmiotem-dodatkowym-11397.html (accessed 07.31.2019).

5 "We can, in fact, spend our youth being distracted, skimming the surface of life, half-asleep, incapable of cultivating meaningful relationships or experiencing the deeper things in life. In this way, we can store up a paltry and unsubstantial future. Or we can spend our youth aspiring to beautiful and great things, and thus store up a future full of life and interior richness." Pope Francis. PostSynodal Apostolic Exhortation: Christus Vivit, Vatican City 2019, no. 19. 
students, and these opportunities can be used to educate them within the difficult conditions of contemporary public schools. ${ }^{6}$ An interesting narrative describing the conversion process took place on the way to Emmaus. After witnessing the events that took place on Good Friday, two disciples faltered in their faith and decided to leave the community of disciples in Jerusalem and return home. In other words, they decided to abandon the faith and pursue other activities. These two men are those for whom the new evangelization is meant because they had belonged entirely to Jesus, but they chose to abandon Him. ${ }^{7}$

How did Jesus respond to these two men, and what does His response tell those who are troubled by the trend of students dropping out of religious education in Polish public schools today? "As they talked and discussed these things with each other, Jesus himself came up and walked along beside them" (Lk 24:15). In this critical moment, Jesus took the initiative. He joined the company of these former disciples, listened to their problems, and was near to them in their brokenness and sadness. First, Jesus silently listened to their conversation and learned about their lives, problems, worries, and fears. Jesus did not try to convert them right away; instead, He engaged them and asked them about ordinary things. He then provoked them to let Him participate in the conversation. Only after a prolonged analysis does Jesus begin to officially evangelize. ${ }^{8}$

In terms of both its plot and methodology, Jesus' approach is instructive and didactic for us today. Jesus does not follow a set formula; instead, with the help of the Bible, He sets new challenges before the disciples. Admittedly, Jesus later celebrates the Eucharist with the disciples, which enables them to recognize Him. Prior to this encounter, however, Jesus simply does not let the disciples return home, and, as a result, the disciples returned to Jerusalem where their faith flourished so greatly that they wanted to share about their encounter with the Lord with others. Jesus' evangelical approach was effective and lasting, and this is where extracurricular religious activities come in. Like Jesus, catechists should not allow catechumens to venture too far from the Church; they need to join catechumens in their walk of life and somehow capture them for Christ by means of offering them

6 Por. W. Pikor, "Dynamika pojednania z Bogiem w Ps 51," in: Dla dobra Jego Ciała, którym jest Kościót, ed. G. Baran, Czestochowa 2019, pg. 364.

7 Por.S.Biel.W drodze do Emaus, https://www.deon.pl/religia/duchowosc-i-wiara/ slowo-boze/art,51,w-drodze-do-emaus.html (accessed 07.31.2019).

See ibid.. 
attractive extracurricular activities that correspond to their interests and in which they will willingly participate. ${ }^{9}$

The fact that students' are abandoning catechesis at school demands that we go out and meet them on a path that lies outside of typical religious education classes. ${ }^{10}$ Today, when numerous students no longer participate in religion classes and have abandoned the Church, catechists - both religious and lay-must set aside moralistic preaching from the pulpit and mundane teaching within the public school classroom and go out to the students themselves, who live in a media-saturated global village, and demonstrate that we are interested in their ordinary problems. Public relations specialist, Monika Przybysz, believes that this effort must be based on "strategic action that adopts a conscious and sustainable concept of communication. [This activity] must have precisely defined goals, strategies, a budget, measures for performance analysis, adaptation procedures, passion, and a readiness to engage in daily and regular work." ${ }^{11}$ We should use strategies that are already available to investigate why students leave religious education and give up the chance to deepen their own Catechetics spiritual development. Today, it is no longer necessary to respond with catechetical formulas; rather, we need to share Jesus of the Holy Scriptures and other people's experiences [of Him]. ${ }^{12}$

\section{Extracurricular Religious Education}

Within the school community, the principal is responsible for organizing extracurricular activities that take place on a school's campus. ${ }^{13}$ Teachers of different subjects, a psychologist, a school pedagogue, the director of a school's club room, and particularly a catechist can assist the principle in organizing extracurricular religious education. ${ }^{14}$

$9 \quad$ Por. P. Goliszek, "Katecheza nowoewangelizacyjna," w: Nowa ewangelizacja w nowej katechezie, ed. P. Mąkosa, Rzeszów 2013, pg. 119.

See Polish Episcopal Conference, Podstawa programowa katechezy Kościoła katolickiego w Polsce Czestochowa 2018, pg.10

Por. M. Przybysz, "Public relations w nowej ewangelizacji," in: Ewangelizacja odpowiedzią Kościoła w Polsce na wyzwania wspótczesności, eds. W. Przygoda, E. Robek. Sandomierz 2011, pgs. 168-169. Ewangelizacja odpowiedzia Kościoła w Polsce, pgs. 168-169.

13 See D. Kowalczyk, Szkoła wobec doświadczeń pozaszkolnych uczniów w dobie elektronicznych środków przekazu, Opole 1999, pg. 7.

14 For more on this topic, please see: A. Panek, Zajęcia pozalekcyjne wreformowanej szkole, Warsaw 2004. 
Extracurricular activities for students require financing. Therefore, a principal must allocate a certain amount of money from the school budget to such classes. If the classes are not offered for free, then students and their parents will not be interested in participating in them because not everyone can afford to do so. It is also worthwhile to make a price comparison for different activities offered at different centers or search for someone who will make an attractive and affordable offer. In addition, a principal must be a capable manager in order to collect the funds necessary to organize attractive extracurricular activities for students. ${ }^{15}$ Catechists should also learn how to fundraise for extracurricular religious education programs through legal action and seeking out friendly sponsors.

Once the necessary funds for extracurricular religious activities have been secured, then a principal must consider which activities are worth organizing. ${ }^{16}$ The best way to determine this is to inform students and parents that extracurricular religious activities will be offered during the following academic year and solicit their feedback ${ }^{17}$ by asking them the following questions: What kind of extracurricular activities (religious, recreational, educational, etc.) would you like to be offered at school and how many additional free activities would you like to participate in? In order to offer the activities in which the students are most interested, those in charge could arrange a meeting during which they can survey the students and get their feedback on which activities students prefer and how many students plan to participate in them.

After the extracurricular activities have been determined, they can be offered after compulsory lessons at school. This will allow the students to take a break from didactic activities. Extracurricular activities can be organized at school, community clubs, cultural centers, sports facilities, or parish pastoral centers. The objectives of extracurricular activities do not have to be identical to the school's teaching methodology, although they should support it. During extracurricular activities,

$15 \quad$ See Komunikat MEN $z$ dn. 10.07.2019 w sprawie wniosków JST o zwiększenie kwot części oświatowej subwencji ogólnej na rok 2019, https://www.gov.pl/web/ edukacja/subwencja-ogolna-dla-jst55 (accessed 08.01.2019).

16 Por. I. Fedorowicz, "Ognisko pracy pozaszkolnej," Życie Szkoły 2004, no. 3, pg. 27.

17 "In cooperation with other teachers in managerial positions and as part of his or her pedagogical supervision, the principal of a school or an institution supports teachers in carrying out their tasks," Rozporzadzenie Ministra Edukacji Narodowej w sprawie nadzoru pedagogicznego. Issued on August 27, 2015 (Dz.U. poz. 1270), § 24.1 . 
students can relax, make new friends among their peers, and develop their own interests in art as well as manual and physical activities. These classes should be designed to help students skillfully manage their free time and give them joy not only in whatever they are doing, but also in discovering the meaning of life within a religious context. ${ }^{18}$

The basic difference between school lessons that students do not always like and extracurricular activities is this: the latter are voluntary. As long as students are interested in the extracurricular activities, they will want to participate. The main argument in favor of organizing extracurricular activities is that they are not compulsory, graded, and repetitive, all of which make them a great context in which to achieve important educational goals. And with particular regard to religious proposals, the effectiveness of the context that extracurricular activities provide cannot be overestimated. ${ }^{19}$

What are the benefits of organizing extracurricular activities to achieve catechetical goals? Extracurricular activities certainly help students develop teamwork skills; provide an opportunity for students to deepen their interest in religion; awaken students' sense of duty; Catechetics and foster altruism, empathy, openness, independence, and consistency. They also create an atmosphere conducive to active listening and sharing one's skills with others. Our past experience organizing such classes affirms that they also provide an opportunity to form and improve students' personalities and characters, especially those upset by moral disorders.

\section{Types of Extracurricular Activities}

Extracurricular activities can be broken down into different categories. Arts-related activities can include music (choir, dance, vocal ensemble, individual instruments, music therapy), theater (pantomime, drama), and graphic arts (religious graphics, bible-inspired sculpture). Sports activities can include gymnastics, football, basketball, volleyball, chess and checkers, karate, and judo. The technical arts can involve model making, sewing, cooking, and baking, along with food

18 A. Duszyńska, “Zajęcia pozalekcyjne-wyznacznik atrakcyjności szkoły,” Nowa szkota 5(1999), pg. 5.

19 Por. G. Grochowski, "Gry i zabawy pozalekcyjne," in: Wokót katechezy posoborowej, eds. R. Chałupniak, J. Kochel, J. Kostorz, W. Spyra, Opole 2014, pg. 103. 
and water conservation. Extracurricular activities can also be classes or interest groups that deepen students' knowledge in different areas. ${ }^{20}$

The variety of potential places where extracurricular activities can be organized and offered demonstrates that a catechist can definitely get involved in many different areas while still carrying out the specific aspects of his or her educational role. Nevertheless, from a catechetical point of view, the following activities are valuable contexts in which to pass on the faith: religious theater, psalm-inspired dance, religious sculpture, religious music and keyboard accompaniment, nature club, Bible study groups, Caritas school groups, vocal classes with Gospel music, and volunteering opportunities. ${ }^{21}$

Extracurricular activities may need to be modified to accommodate the blind and hearing impaired. When this is the case, however, they are not always optional. For example, such activities can become compulsory if a teacher, school counselor, psychologist, catechist, or parent refers or requires a student to participate in certain activities. ${ }^{22}$

\section{Who Can Organize and Lead Extracurricular Activities}

Extracurricular activities can be conducted by anyone who has an idea, knows how to determine the purpose of these classes, and can achieve their final aim. In the case of extracurricular religious activities, the person who leads them must know the teachings of the Catholic Church and faithfully live according to the principles of Christian faith and morality. ${ }^{23}$ To solicit leaders, a principal can organize a competition for interesting activities among his teachers. He or she can also submit an announcement to the press or to on an online forum stating that the school is seeking people with interesting ideas for religious extracurricular education. In addition, a principal, teachers, and anyone aware of the need can always personally seek out specialists with experience in teaching specific classes. ${ }^{24}$

20

Por. A. Duszyńska, Zajęcia pozalekcyjne - wyznacznik atrakcyjności szkoły, pg. 6.

21

Por.Z.Maciejewski, "Motywacja w katechezie,”w: Wokótkatechezy posoborowej, pg. 289.

See Głomski, "Program profilaktyczno-wychowawczy 'Czas wolny inaczej," Problemy Opiekuńczo-Wychowawcze, 2001, no. 6, pgs. 20-21.

23

Por. T. Dąbek, "Posłannictwo tłumacza i komentatora Biblii według Pisma Świętego," in: Dla dobra Jego Ciała, pg. 144.

24

Por. A. Duszyńska, Zajęcia pozalekcyjne - wyznacznik atrakcyjności szkoty, pg. 7 . 
Anyone who is interested in organizing and teaching extracurricular religious activities should inform the principal in writing and explain how the activity is related to the school's curriculum and its main objectives. The interested party should also be required to describe what he intends the students to achieve, by what means and methods he plans to help students reach these goals, and a list of the teaching aids and materials needed to facilitate the classes. Since the role of extracurricular religious activities is very important, the principal should always request that the aforementioned information be submitted in writing. This then gives a principal the opportunity to accept or reject the person conducting the classes. ${ }^{25}$ When a principal doubts the ability of a person who expresses a readiness to teach extracurricular classes, he or she can arrange a demonstration lesson in order to observe the candidate's teaching style, skills, rapport with students, and individual strengths and weaknesses.

Whoever teaches extracurricular activities should also plan to keep a record not only of the main objectives of the class and lesson plans, but also the days on which specific lessons will take place and student Catechetics attendance. It is worthwhile for the teacher to keep these records in a way that involves and is attractive to the participants. ${ }^{26}$ This will also allow teachers to evaluate whether the classes are well organized and how popular they are based on student attendance.

Extracurricular activities that promote student creativity should take priority. Therefore, when planning the activities, organizers should seek to find a location on the school campus that enables students to freely create and display their own achievements. Exhibitions and performances are the best way to promote extracurricular activities and entice other students to participate in them in the future. For example, those who lead extracurricular activities can organize a performance during the school year. During this performance, students can pray together and showcase their different talents such singing, playing instruments, reciting poems, dancing, pantomiming, photography, and artwork. ${ }^{27}$

The possibilities for extracurricular religious activities are as numerous as the well-managed schools and teachers of religious education

Por.Z. Barciński, ed., Vademecum katechety. Metody aktywizujace, Lublin 2006, pg. 15 .

26 Por. Licealista stworzył system, który automatycznie sprawdza obecność na lekcji, https://dzienniklodzki.pl/licealista-stworzyl-system-ktory-automatyczniesprawdza-obecnosc-na-lekcji/ar/3374145 (accessed 07.22.2019).

27 Por. A. Duszyńska, Zajęcia pozalekcyjne - wyznacznik atrakcyjności szkoty, pg. 9. 
willing to offer them. It is, therefore, worthwhile for a school or diocese to keep a record of interesting ideas for extracurricular religious activities so that those who are interested in organizing a class or group can find inspiration.

\section{The Benefits of Extracurricular Activities}

Extracurricular activities have diverse educational benefits. For example, schools that offer a large number of extracurricular activities have higher rankings, and schools that teach religion serve as a reminder of the inspirational power of the Gospel in education. ${ }^{28}$ Classes that incorporate religious elements give children a chance to deepen their religious knowledge and nurture their spiritual, physical, intellectual, and social development. Extracurricular religious education also creates a great opportunity for children to grow in self-confidence and strengthen their own abilities while helping them fulfill the dreams that are left unfulfilled by a religion lessons taught during the school day.

Extracurricular activities also provide an occasion for educators to "capture" talented children who have the potential to achieve a lot Catechetics through individual instruction. In addition, during extracurricular activities, educators have a unique opportunity identify children in terms of their practical capabilities and intellectual predispositions.

Extracurricular classes are a great way for children who require after-school care to spend their time. They also provide students with an opportunity to make new friends with children from other classes and educational levels and to learn how to deal with new and difficult situations.

\section{The Drawbacks of Extracurricular Activities}

Preaching the word of God through extracurricular activities is closely connected with listening to modern man. Only through listening is it possible to take advantage of the different occasions to communicate the Gospel that arise. According to Pope Emeritus Benedict XVI, listening makes it possible to acknowledge deep cultural changes that manifest themselves in new languages and new forms of communication. These, in turn, contribute to the emergence of new and problematic types of anthropology. For this reason, ordinary catechists encounter difficulties in proclaiming the Gospel within the Church itself. This happens, for example, when they teach the baptized who

Francis, Christus vivit, no. 1. 
do not believe or are indifferent, and, therefore, perceive what they are learning as ineffective and unattractive. In this day and age, using new languages and forms of communication while remaining faithful to the deposit of the faith is an effective strategy for evangelization. Educators and religious leaders' inability to communicate the meaning and beauty of the Gospel through clear and understandable language may be one reason why young people are abandoning God. This is why a new community of Church thought and baptized man are necessary required, which Benedict XVI refers to as "tun[ing] in to the same frequency." 29

Organizing extracurricular activities has its pros and cons. One of the main obstacles is insufficient finances to ensure that the activities are of a high quality and level. In addition, the reformed Polish education system and resulting the double-shift school day pose certain difficulties because schools become inundated with students during the transitional hour, which results in a lack of classroom space for extracurricular activities. Spending many compulsory hours at school also imposes a significant burden on children, so they are usually too Catechetics tired to fully and effectively participate in extracurricular classes. This difficult situation can also be compounded by the fact that parents want their children to participate in as many activities as possible, which makes the activities less attractive to and effective for students, even if they are actually interested in them..$^{30}$

Furthermore, the Polish education system offers relatively few teaching aids and resources to offer extracurricular activities. And, when activities are offered, teachers do not use effective activating methods, so the classes are unattractive to students. In addition, very few specialists are available to teach extracurricular activities, and conversely, few extracurricular courses are available to teachers who would like to increase their qualifications in this area. ${ }^{31}$

Difficulties may also arise due to a lack of motivation on the part of children, who overestimate the importance of social and multimedia and allocate their free time to these areas. Even if children choose to participate in extracurricular activities, their motivation may be

$29 \quad$ Benedict XVI. Address of His Holiness Benedict XVI to the Participants in the Plenary Assembly of the Pontifical Council for Culture, November 13, 2010. https://w2.vatican.va/content/benedict-xvi/en/speeches/2010/november/documents/hf_ben-xvi_spe_20101113_pc-cultura.html (accessed 09.10.2019).

30 Por. A. Duszyńska, Zajęcia pozalekcyjne - wyznacznik atrakcyjności szkoty, pg. 10.

$31 \quad$ Por. K. Nycz, "Kościół w szkole czy szkoła w Kościele?," Pastores 16(2002) no. 2, pgs. 17-18. 
short-lived when the educational priorities of their parents change. Additionally, students might participate passively in extracurricular activities as a way of "avoiding" being at home.

Despite potential difficulties, extracurricular activities are becoming a great way to effectively provide religious instruction to students who drop out of religious education classes during the school day and to develop and expand students' knowledge of theology and religion.

\section{Possible Suggestions for Extracurricular Religious Activities}

Among solutions to the problem of students abandoning religious education offered at school, Karl Rahner's prophetic proposal is the most interesting: "The Christian of the future will be a mystic or he will not exist at all."32 If Rahner's statement is, in fact, true, then it reveals why it is so important to offer a different approach to religious formation (i.e., through extracurricular activities)—an approach that is not associated with the electronic agendas, tests, and moralizing only. ${ }^{33}$ At the same time, the Gospel must be presented in a modern, decisive, and clear way as the key to deciphering the meaning of life, a recipe for happiness, and a source of hope. ${ }^{34}$

Unconventional methods are nevertheless still required to present other people's faith experience. As observations demonstrate and research confirms, unconventional approaches to catechesis are of interest. ${ }^{35}$ We live in a time when it is difficult to engage and commu-

$32 \quad$ K. Rahner, "Elemente der Spiritualität in der Kirche der Zukunft," in: Schriften zur Theologie, vol. 14. Einsiedeln-Benziger 1980, pg. 375.

Por. A. Komornicka, Zagadki z Biblii, Tradycji i kultury chrześcijańskiej, Marki 2000 , pg. 6.

"For every believer and for every person, God is the ultimate answer to the search for happiness and meaning." Pontifical Biblical Commission, Biblia a moralność. Biblijne korzenie postępowania chrześcijańskiego, trans. R. Rubinkieiwcz, Kielce 2009, pg. 15.

Attractive hobbies can help catechists in their efforts to attract young people to the faith. For example: Fr. Witold Bock dives $60 \mathrm{~m}$ below sea level. Fr. Paweł Łukaszka was the best hockey goalkeeper in Europe in 1979 and later became an idol for youth. Fr. Krzysztof Gardyna likes to share with stories about his experiences in the Himalayas. Fr.. Andrzej Jaskuła created the Christian School of Sailing and takes young people sailing. Por. A. Potocki, Wychowanie religijne $w$ polskich przemianach, Warsaw 2007, pgs. 373-374. 
nicate with students without multimedia. For this reason, catechists must expand significantly on their use of audiovisual media. ${ }^{36}$

During extracurricular activities, courses on evangelization (or its most important elements) can be offered. In this regard, the Philip course should take precedence. In principle, preaching the kerygma should be supported by personal testimony and directed to the participant's will rather than to his intellect. ${ }^{37}$ The purpose of the Alpha course is the same as the Philip course, but it was developed as a response to secularization, which also affects contemporary Polish schools. ${ }^{38}$ The Alpha course is intended not only for people outside of the Church and for new converts, but also for those who want to deepen their faith. ${ }^{39}$

Those leading extracurricular activities should be introduced to elements of religious formation that focus not on the transmission of intellectual content but on forming the human personality. ${ }^{40}$ Both liturgical and biblical methods will enable students to interiorize and carry on the truths that they have learned. Among other things, these methods include: group meetings, celebrations, activities, ${ }^{41}$ schools of prayer, and biblical study, including lectio divina. ${ }^{42}$

An excellent opportunity for a catechist to engage with students is through the development of religious movements and associations in order to re-evaluate existing practice. ${ }^{43}$ However, it is worth recalling Cardinal J. Ratzinger's observation that "Large things always begin from the small seed, and the mass movement are always ephemeral." ${ }^{4}$ Therefore, catechists cannot be discouraged even when the effects of

Por. P. Makosa, Największa jest Miłość. Ewangelizacyjny Katechizm Młodych, Lublin 2015.

Kurs Filip, http://www.hieronim.przemysl.opoka.org.pl/formacja/sne.doc (accessed 06.08.2018).

T. Stilwel, Alfa dla mtodzieży. Podręcznik lidera, Warsaw 1998, pg. 5.

S. Jones, Alfa dla dzieci, Warsaw 1999.

Por. Z. Barciński, Leksykon metod aktywizujacych, pg. 169.

Polish Episcopal Conference. Dyrektorium katechetyczne Kościoła katolickiego $w$ Polsce. Cracow 2001, no. 107.

J. Kochel, "Szkoła Słowa Bożego w programie katechezy parafialnej," Katecheta 1(2005), pgs. 46-51.

Por. T. Husarek, M. Fiałkowski, A. Drzycimski, Fenomen niewiary w świetle dialogicznej natury Kościoła, Torun 2018, pg.142.

J. Ratzinger. Nowa ewangelizacja. Przemówienie prefekta Kongregacji Nauki Wiary 9.12.2000 r. Rzymie. http://www.opoka.org.pl/biblioteka/W/WR/inne/ ratzinger_ewangelizacja.html (accessed 08.06.2019). 
their educational efforts are not readily apparent. It is important to involve all those responsible and trust Jesus who said: "Heaven and earth will pass away, but my words will never pass away"' (Mt 24:35).

Only the very best educators can achieve these goals during extracurricular activities. Therefore, catechists who intend to be involved in this work must belong to the spiritual elite. For almost two decades, the Church has emphasized that evangelization should be carried out in the "style of Jesus himself, who catechized by word, deed, and his entire life" 45 Only then can extracurricular activities become a real scope for evangelization, in which people, sociability, flexibility, openness, and conviction are the most important. ${ }^{46}$ Catechists - the guides for schools' religious communities-are called to participate most in this endeavor. They should show that the Church is alive and that it is the future of the world. ${ }^{47}$

\section{Conclusion}

The evangelization of students who have decided to drop out of religious education at school must be personal, take the individual into account, or be implemented in small groups as part of extracurricular activities. In this endeavor, it is necessary to determine what caused a person to abandon Jesus and to take the necessary steps to not only lead him to accept theoretical knowledge about the Savior, but to also return to religion and Christ's teachings. In conclusion, when caring for students who do not see any sense in participating in school religion lessons by offering extracurricular activities, many of their other developmental needs can be met at the same time. Therefore, these activities are an obvious pastoral option. Spiritual renewal among these students is possible and, with God's help, always effective.

Religious education is offered in Polish public schools as part of the school curriculum and based on the parents or students' declaration of intent to participate. Recently, however, there has been a tendency, especially among high school students, to drop out of religious education

$45 \quad$ W. Lisowski, trans., A. Bałoniak, ed., Kapłan a katecheza w Europie. Kongres Biskupówi Odpowiedzialnych Krajowych za katechizację w Europie (Rome, May 5-8, 2003), Poznan 2003 pg. 108.

46

47

Ibid.

Pope Francis reminds the youth that "Christ is alive and he wants you to be alive!" in his Post-Synodal Apostolic Exhortation Christus vivit, no. 1. 
classes due to catechists' reluctance to explore certain religious topics and because student are giving in to the influence of secularization, which rejects the importance of spiritual reality. Extracurricular religious activities are an effective means to either stop or reverse this disturbing trend. The aim of these activities is to prevent students from leaving the Church. The basic difference between school lessons and extracurricular activities is that students freely choose to participate in the latter. Such classes help students develop teamwork skills, give them a chance to deepen their religious interests, and provide organizers with an opportunity to foster altruism, empathy, openness, independence, and consistency among their pupils. Extracurricular activities can offer a wide array of artistic, theatrical, graphic, sports, and technical enrichment. From the catechetical perspective, religious theater, psalm-inspired dance, religious sculpture, religious music and keyboard instruments, nature clubs, Bible study clubs, Caritas clubs, vocal classes with Gospel music, and volunteer opportunities are the most valuable for passing on the faith. Extracurricular religious activities can be conducted by anyone who is willing to organize them

Catechetics and achieve the end result. Catechists and organizers should choose activities that will foster a variety of student works and creations. The educational benefits of teaching religion is to demonstrate the everinspiring power of the Gospel in education. The main obstacles that individuals encounter when organizing extracurricular activities are a lack of funds and double-shift schools. In addition, sufficient teaching aids and materials and a lack of student motivation are issues. The most important aim of extracurricular religious education is to present a different image of religious formation so that students do not associate religious education with the grades, testing, and moralizing. These activities must seek to clearly propose the Gospel as the key to interpreting the meaning of life and a recipe for happiness. Interesting hobbies and unusual creativity are additional and helpful means through which religion teachers can present other people's experience of the faith.

\section{Bibliography:}

1. Barciński Z., ed., Vademecum katechety. Metody aktywizujace, Lublin 2006.

2. Benedict XVI, Address of His Holiness Benedict XVI to the Participants in the Plenary Assembly of the Pontifical Council for Culture, November 13, 2010. https://w2.vatican.va/content/benedict-xvi/en/speeches/2010/november/documents/hf_ben-xvi_spe_20101113_pc-cultura.html (accessed 09.10.2019). 
3. Biel S., W drodze do Emaus, https://www.deon.pl/religia/duchowosc-i-wiara/slowo-boze/art,51,w-drodze-do-emaus.html (accessed 07.31.2019).

4. Czekalski R., "Nowe formy ewangelizacji w środowisku szkolnym," in: Ewangelizacja odpowiedzia Kościoła w Polsce na wyzwania wspótczesności, eds. W. Przygoda, E. Robek. Sandomierz 2011.

5. Duszyńska A., "Zajęcia pozalekcyjne - wyznacznik atrakcyjności szkoły," Nowa szkoła 5(1999).

6. Dąbek T., "Posłannictwo tłumacza i komentatora Biblii według Pisma Świętego," in: Dla dobra Jego Ciała, którym jest Kościót, ed. G. Baran, Czestochowa 2019.

7. Fedorowicz I., “Ognisko pracy pozaszkolnej,” Życie Szkoły 2004, no. 3, pg. 27.

8. Francis, Post-Synodal Apostolic Exhortation: Christus Vivit, Vatican City 2019.

9. Goliszek P., "Katecheza nowoewangelizacyjna," w: Nowa ewangelizacja w nowej katechezie, ed. P. Mąkosa, Rzeszów 2013.

10. Grochowski G., "Gry i zabawy pozalekcyjne," in: Wokót katechezy posoborowej, eds. R. Chałupniak, J. Kochel, J. Kostorz, W. Spyra, Opole 2014.

11. Głowacki A., Religijność młodzieży i uczestnictwo w lekcjach religii w szkole, in: Centrum Badania Opinii Społecznej, Młodzież 2018, Warsaw 2018.

12. Husarek T., Fiałkowski M., Drzycimski A., Fenomen niewiary w świetle dialogicznej natury Kościoła, Torun 2018.

13. Jones S., Alfa dla dzieci, Warsaw 1999.

14. Kochel J., "Szkoła Słowa Bożego w programie katechezy parafialnej," Katecheta 1(2005).

15. Komornicka A., Zagadki z Biblii, Tradycji i kultury chrześcijańskiej, Marki 2000.

16. Komunikat MEN z dn. 10.07.2019 w sprawie wniosków JST o zwiększenie kwot części oświatowej subwencji ogólnej na rok 2019, https:/www.gov.pl/ web/edukacja/subwencja-ogolna-dla-jst55 (accessed 08.01.2019).

17. Kowalczyk D., Szkoła wobec doświadczeń pozaszkolnych uczniów w dobie elektronicznych środków przekazu, Opole 1999.

18. Licealista stworzyt system, który automatycznie sprawdza obecność na lekcji, https://dzienniklodzki.pl/licealista-stworzyl-system-ktory-automatycznie-sprawdza-obecnosc-na-lekcji/ar/3374145 (accessed 07.22.2019).

19. Lisowski W., trans., Bałoniak A., ed., Kapłan a katecheza w Europie. Kongres Biskupów i Odpowiedzialnych Krajowych za katechizację w Europie (Rome, May 5-8, 2003), Poznan 2003.

20. Maciejewski Z., "Motywacja w katechezie," w: Wokót katechezy posoborowej, eds. R. Chałupniak, J. Kochel, J. Kostorz, W. Spyra, Opole 2014.

21. Makosa P., Największa jest Miłość. Ewangelizacyjny Katechizm Młodych, Lublin 2015.

22. Nycz K., "Kościół w szkole czy szkoła w Kościele?,” Pastores 16(2002) no. 2.

23. Panek A., Zajęcia pozalekcyjne w reformowanej szkole, Warsaw 2004.

24. Pikor W., "Dynamika pojednania z Bogiem w Ps 51," in: Dla dobra Jego Ciała, którym jest Kościót, ed. G. Baran, Czestochowa 2019. 
25. Polish Episcopal Conference, Podstawa programowa katechezy Kościoła katolickiego $w$ Polsce Czestochowa 2018.

26. Polish Episcopal Conference. Dyrektorium katechetyczne Kościoła katolickiego $w$ Polsce. Cracow 2001.

27. Pontifical Biblical Commission, Biblia a moralność. Biblijne korzenie postępowania chrześcijańskiego, trans. R. Rubinkiewicz, Kielce 2009.

28. Potocki A., Wychowanie religijne w polskich przemianach, Warsaw 2007.

29. Przybysz M., "Public relations w nowej ewangelizacji," in: Ewangelizacja odpowiedzia Kościoła w Polsce na wyzwania wspótczesności, eds. W. Przygoda, E. Robek. Sandomierz 2011.

30. Rahner K., "Elemente der Spiritualität in der Kirche der Zukunft," in: Schriften zur Theologie, vol. 14. Einsiedeln-Benziger 1980.

31. Ratzinger J.. Nowa ewangelizacja. Przemówienie prefekta Kongregacji Nauki Wiary 9.12.2000 r. Rzymie. http://www.opoka.org.pl/biblioteka/W/ WR/inne/ratzinger_ewangelizacja.html (accessed 08.06.2019).

32. Stilwel T., Alfa dla mtodzieży. Podręcznik lidera, Warsaw 1998.

33. Zaleśny L., Zajęcia z religii - czy sa przedmiotem dodatkowym? https:// www.portaloswiatowy.pl/organizacja-zajec-szkolnych/zajecia-z-religii-czy-sa-przedmiotem-dodatkowym-11397.html (accessed 07.31.2019). 